\title{
DEVELOPMENT AND VALIDATION OF RP-HPLC METHOD FOR THE ESTIMATION OF TRIFLUSAL IN BULK AND IN CAPSULE FORMULATION
}

\author{
VIJAY K. PATIL, VIVEKKUMAR K. REDASANI*, KULDIP R. VISPUTE, SANJAY J. SURANA
}

\author{
Department of Pharmaceutical Chemistry, R. C. Patel Institute of Pharmaceutical Education and Research, Shirpur (Dhule) - 425405 Maharashtra, [India] \\ R. C. Patel Institute of Pharmaceutical Education and Research, Karwand Naka \\ Shirpur, Dhule [425 405] MS, India.
}

(Received: December 29, 2011 - Accepted: March 6, 2012)

\begin{abstract}
A simple, rapid, selective and sensitive RP-HPLC method was developed and validated for the estimation of triflusal. The method was carried out using 5- $\mu \mathrm{m}$ particle size, C18-bonded silica column, quaternary pump and acetonitrile: $1 \mathrm{mM}$ potassium dihydrogen phosphate $(65: 35 \mathrm{v} / \mathrm{v}) \mathrm{pH} 3$ as the mobile phase with UV detection at $226 \mathrm{~nm}$. The proposed method is advantageous as it follows isocratic elution in short run time (10 min). The result obtained shown that the method best fits for estimation of drug in capsule formulation and thus can be used for its routine analysis. The newly developed method was validated according to the ICH guidelines with respect to specificity, linearity, accuracy, precision and robustness.
\end{abstract}

Keywords: Triflusal, RP-HPLC, Validation, Specificity, System suitability

\section{INTRODUCTION}

Triflusal (TRI) Fig 1, a benzoic acid derivative, is chemically 2-(acetyloxy)4-(trifluoromethyl) benzoic acid, having molecular formula $\mathrm{C}_{10} \mathrm{H}_{7} \mathrm{~F}_{3} \mathrm{O}_{4}$, molecular weight $248.155 \mathrm{gm} / \mathrm{mol}$ and melting point $118^{\circ} \mathrm{C}^{1}$.<smiles>CC(=O)Oc1cc(C(F)(F)F)ccc1C(=O)O</smiles>

Figure 1 Chemical structure of Triflusal

The estimation of TRI is vital as the drug has multiple modes of action that added value in its definitive pharmacological effect. Apart from inhibition of prostaglandin synthesis as it resembles with that of aspirin, the drug also shows preservation of prostacyclin, blockage of phosphodiesterase thereby increasing cAMP concentration. It also acts as an antiplatelet agent that involves blockage of cyclooxygenase inhibiting thromboxane $\mathrm{A}^{2}$.

The detail literature survey revealed few analytical methods reported for evaluation TRI such as HPLC ${ }^{3-5}$. HPLC with automated column switching system ${ }^{6}$, spectroscopic and chromatographic characterization using supercritical impregnation technologies ${ }^{7,8}$.

Promoted by above findings and the ultimate therapeutic utility of TRI, previously we have estimated the drug by simple UV spectrophotometric method 9 . In continuation to that, in the present work the estimation of TRI was done by more sophisticated technique i.e. using reverse-phase high-performance liquid chromatographic (RP-HPLC) method. With the objective of reducing analysis time and maintaining good efficiency, there has been substantial focus on highspeed chromatographic separations. Methods proposed for analytical purposes must be as economical as possible, to enable their use in routine quality control. Many spectroscopic methods have been proposed for analysis of similar drug but for the first time we are describing simple, sensitive, accurate, precise, rapid and economic chromatographic method for TRI in capsule dosage form. Our objective in the present investigation is to develop and validate an RP-HPLC method for estimation of triflusal (TRI) and their analysis in capsule.

\section{EXPERIMENTAL}

Chemicals \& Reagents

Pure drug sample of TRI was obtained from Grenmark Pharmaceuticals
Ltd., Nasik (India), HPLC grade acetonitrile and methanol was obtained from Merck India Ltd., HPLC grade water was obtained from Milli-Q water purification system (Millipore Co., Milford, MA, USA) and used throughout the study. All the solvents and solutions were filtered through a membrane filter (Millipore Millex ${ }^{\circledR}$ FH, filter units, Durapore-PVDF, Polyethylene, $0.45 \mu \mathrm{m}$ pore size) and degassed before use. Drug formulation (capsule) Grendis ${ }^{\mathbb{\circledR}}$ with label claim $300 \mathrm{mg}$ is used for estimation.

\section{Sample preparation}

Stock solutions $(100 \mu \mathrm{g} / \mathrm{mL})$ of TRI were prepared in HPLC grade methanol. The standard was prepared by progressive dilution of the stock solution.

\section{Chromatographic Conditions}

Analysis was performed on Agilent HPLC 1200 series separation module with in-built PDA detector. Chromatographic software Ezechrome Elite was used for data collection and processing. The analytical column was Hypersil BDS $\mathrm{C}_{18}(250 \mathrm{~mm} \mathrm{X} 4.6 \mathrm{~mm}, 5 \mu \mathrm{m}$ particle size $)$ with the mobile phase acetonitrile: $1 \mathrm{mM}$ potassium dihydrogen phosphate $(65: 35 \mathrm{v} / \mathrm{v}), \mathrm{pH}$ of buffer was maintained at $3 \pm 0.05$ with $\mathrm{H}_{3} \mathrm{PO}_{4}$. Mobile phase is degassed and filtered through $0.45 \mu \mathrm{m}$ pore size membrane filter prior to operating under isocratic condition. Flow rate is kept as $1.0 \mathrm{~mL} / \mathrm{min}$. Sample injection volume was $20 \mu \mathrm{L}$ and column oven temperature was maintained at $25^{\circ} \mathrm{C}$, elution was monitored at $226 \mathrm{~nm}$ with run time $10 \mathrm{~min}$.

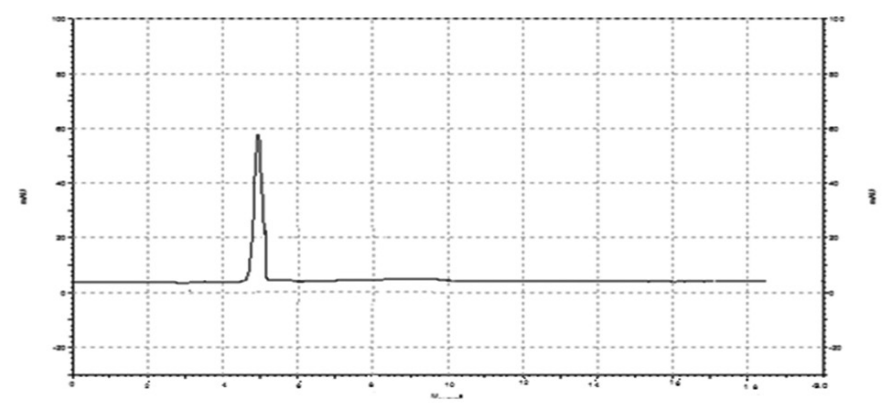

Figure 2 Typical chromatogram of Triflusal showing retention time 5.3

Analysis of the capsule dosage form:

Twenty capsules (Grendis ${ }^{\circledR} 300 \mathrm{mg}$ ) were weighed accurately and crushed to form fine powder. Powder weight equivalent to $10 \mathrm{mg}$ of TRI were dissolved in $100 \mathrm{~mL}$ volumetric flask with methanol. It was sonicated followed by filtration using Whatmann filter paper No. 1. Appropriate volumes of the aliquot were transferred into six different $10 \mathrm{~mL}$ volumetric flasks and the 
volume was made up to the mark with mobile phase to get concentration 6 $\mu \mathrm{g} / \mathrm{mL}$ of TRI. The solutions were subject to analysis and results obtained as in Table 1.

Table 1 Assay of triflusal capsule formulation.

\begin{tabular}{|c|c|c|c|}
\hline $\begin{array}{c}\text { Amount taken } \\
{[\boldsymbol{\mu} \mathbf{g} / \mathbf{m L}]}\end{array}$ & $\begin{array}{c}\text { Amount found } * \\
{[\boldsymbol{\mu g} / \mathbf{m L}] \text { Mean } \pm \mathbf{S D}}\end{array}$ & $\begin{array}{c}\text { \% Amount } \\
\text { Found }\end{array}$ & \% RSD \\
\hline 6 & $6.06 \pm 0.07$ & $100.63 \pm 1.2$ & 1.26 \\
\hline$* \mathrm{n}=6$
\end{tabular}

Validation Parameters

The developed method was validated as per ICH guidelines in terms of its linearity, accuracy, Limit of detection (LOD), Limit of quantification (LOQ), specificity, intra-day and inter-day precision and repeatability of measurement ${ }^{10}$.

\section{Linearity}

Appropriate aliquots of standard stock solution were taken in different 10 $\mathrm{mL}$ volumetric flasks and diluted up to the mark with mobile phase to obtain final concentrations of 2, 4, 6, 8 and $10 \mu \mathrm{g} / \mathrm{mL}$ The solutions were injected using a $20 \mu \mathrm{L}$ fixed loop system and chromatograms were recorded. TRI follow linearity in range 2 to $12 \mu \mathrm{g} / \mathrm{mL}$ and result are tabulated in Table 2.

Table 2 Linearity data for triflusal.

\begin{tabular}{|c|c|}
\hline Parameters & Results* $^{*}$ \\
\hline Linearity range $(\mu \mathrm{g} / \mathrm{mL})$ & 2 to 12 \\
\hline Slope & 30346 \\
\hline Intercept & 38307 \\
\hline Correlation coefficient $\left(\mathrm{r}^{2}\right)$ & 0.999 \\
\hline & \\
\hline
\end{tabular}

Accuracy

Accuracy was found by studying level of recovery using standard addition method. Known amounts of standards of TRI was added to pre-analyzed samples at a level from $80 \%$ to $120 \%$ and then subjected to the proposed HPLC method. The solutions were then analyzed, and the percentage recoveries were calculated by using formula.

\section{$\%$ Recovery= \\ Observed amount of compound in Sample}

\section{Amount of all compound present in Sample}

Results obtained are tabulated in Table 3 .

Table 3 Accuracy study of triflusal by RP-HPLC method

\begin{tabular}{|c|c|c|c|}
\hline $\begin{array}{c}\text { Level of } \\
\text { recovery }\end{array}$ & $\begin{array}{c}\text { Amount of drug } \\
\text { added }(\boldsymbol{\mu g} / \mathbf{m L})\end{array}$ & \% Recovery* & \% RSD \\
\hline $80 \%$ & 8 & 98.52 & 1.04 \\
\hline $100 \%$ & 10 & 100.92 & 1.08 \\
\hline $120 \%$ & 12 & 101.24 & 0.99 \\
\hline$*_{n}=6$
\end{tabular}

\section{Precision}

Intraday and interday precision of the assay samples containing TRI having concentrations of $4,6,8 \mu \mathrm{g} / \mathrm{mL}$ were analyzed three times in the same day (intraday) and for three consecutive days (interday). Precision was calculated as intra and interday coefficient of variation $[\%$ C.V. $=($ S. D. $/$ mean $) \times 100]$ as shown in the Table 4.
Table 4 Precision data of triflusal by RP-HPLC.

\begin{tabular}{|c|c|c|c|c|}
\hline \multirow{2}{*}{$\begin{array}{c}\text { Conc. } \\
{\left[\boldsymbol{\mu g} \mathbf{~ m L}^{-1}\right]}\end{array}$} & \multicolumn{2}{|c|}{$\begin{array}{c}\text { Intra-day } \\
\text { Amount found }[\boldsymbol{\mu g} / \mathbf{m L}]\end{array}$} & \multicolumn{2}{c|}{$\begin{array}{c}\text { Inter-day } \\
\text { Amount found }[\boldsymbol{\mu g} / \mathbf{m L}]\end{array}$} \\
\cline { 2 - 5 } & Mean & \% RSD* & Mean & \% RSD* \\
\hline 4 & 3.99 & 1.65 & 5.8 & 1.41 \\
\hline 6 & 6.01 & 1.38 & 5.67 & 1.25 \\
\hline 8 & 8.01 & 1.28 & 8.34 & 1.23 \\
\hline
\end{tabular}

\section{Robustness}

Robustness studies are performed by introducing deliberately small changes in the mobile phase composition $( \pm 5 \mathrm{~mL})$, $\mathrm{pH}$ of mobile phase $( \pm 0.2)$, flow rate $( \pm 0.1 \mathrm{~mL} / \mathrm{min})$ and wavelength $( \pm 2 \mathrm{~nm})$. Robustness of the proposed method is studied and results tabulated in Table 5 .

Table 5 Robustness Studies.

\begin{tabular}{|c|c|c|c|}
\hline $\begin{array}{c}\text { Chromatographic } \\
\text { Conditions }\end{array}$ & $\begin{array}{c}\text { Retention } \\
\text { time }\end{array}$ & $\begin{array}{c}\text { Tailing } \\
\text { factor }\end{array}$ & $\begin{array}{c}\text { Theoretical } \\
\text { Plates }\end{array}$ \\
\hline \multicolumn{4}{|c|}{ A: Flow rate (mL/min) } \\
\hline 0.9 & 5.49 & 1.17 & 7486 \\
\hline 1.0 & 5.31 & 1.40 & 7426 \\
\hline 1.1 & 5.15 & 1.41 & 7590 \\
\hline Mean \pm SD & $\mathbf{5 . 3 1} \pm \mathbf{0 . 1 7}$ & $\mathbf{1 . 3 2} \pm \mathbf{0 . 1 3}$ & $\mathbf{7 5 0 0 \pm} \mathbf{8 2}$ \\
\hline
\end{tabular}

B: Change in mobile phase composition

\begin{tabular}{|c|c|c|c|}
\hline (acetonitrile: buffer & & & \\
$60: 40 \mathrm{v} / \mathrm{v}$ ) & 5.95 & 1.70 & 7340 \\
(acetonitrile: buffer & 5.31 & 1.48 & 7470 \\
$65: 35 \mathrm{v} / \mathrm{v}$ ) & 5.10 & 1.48 & 7580 \\
$\begin{array}{c}\text { (acetonitrile: buffer } \\
70: 30 \mathrm{v} / \mathrm{v} \text { ) }\end{array}$ & & & \\
\hline Mean \pm SD & $\mathbf{5 . 4 5} \pm \mathbf{0 . 1 4}$ & $\mathbf{1 . 5 2} \pm \mathbf{0 . 1 6}$ & $\mathbf{7 4 6 3} \pm \mathbf{1 2 0}$ \\
\hline
\end{tabular}

\begin{tabular}{|c|c|c|c|}
\hline \multicolumn{4}{|c|}{ C: Detection wavelength (nm) } \\
\hline 224 & 5.30 & 1.73 & 7540 \\
\hline 226 & 5.31 & 1.40 & 7452 \\
\hline 228 & 5.29 & 1.74 & 7690 \\
\hline $\begin{array}{c}\text { Mean } \pm \text { SD } \\
\text { phase }\end{array}$ & $\mathbf{5 . 3 0} \pm \mathbf{0 . 0 1}$ & $\mathbf{1 . 6 2} \pm \mathbf{0 . 1 9}$ & $\mathbf{7 5 6 0} \pm \mathbf{1 2 0}$ \\
\hline 2.8 & & & 7468 \\
\hline 3.0 & 5.28 & 1.73 & 7452 \\
\hline 3.2 & 5.30 & 1.40 & 7524 \\
\hline Mean \pm SD & $\mathbf{5 . 3 1} \pm \mathbf{0 . 0 3}$ & $\mathbf{1 . 6 7 \pm 0 . 2 4}$ & $\mathbf{7 4 8 1} \pm \mathbf{3 7}$ \\
\hline
\end{tabular}

Limit of detection (LOD) and Limit of quantification (LOQ)

The LOD and LOQ were calculated by using the equations LOD $=3.3 \times$ $\mathrm{N} / \mathrm{B}$ and $\mathrm{LOQ}=10 \times \mathrm{N} / \mathrm{B}$ where ' $\mathrm{N}$ ' is the standard deviation of the peak areas of the drug $(n=3)$ and ' $\mathrm{B}$ ' is the slope of the corresponding calibration plot. The signal to noise ratio was determined. The LOD was regarded as the amount for 
which the signal to noise ratio was 3:1 and LOQ regarded as the amount for which the signal to noise ratio was 10:1.

\section{RESULTS AND DISCUSSION}

A RP-HPLC method was optimized with a view to develop an accurate and reproducible method for triflusal. Isocratic elution is simple, requires only one pump and flat baseline separation for easy and reproducible results.

The final chromatographic conditions are set for stationary phase giving satisfactory resolved peak and run time with reversed phase Hypersil BDS $\mathrm{C}_{18}$ ( $250 \mathrm{~mm}$ X $4.6 \mathrm{~mm}, 5 \mu \mathrm{m}$ particle size) column. A series of mobile phases varying the $\mathrm{pH}$ and volume fractions of methanol and water are also tested and the best results were obtained by the use of mobile phase consisting of acetonitrile: $1 \mathrm{mM}$ potassium dihydrogen phosphate buffer ( $\mathrm{pH} 3)$, in 65:35 giving well resolved, sharp peak for TRI with a retention time (Rt) of 5.3 Fig 2. The flow rate of $1.0 \mathrm{~mL} / \mathrm{min}$ at $226 \mathrm{~nm}$ and ambient temperature $\left(25^{\circ} \mathrm{C}\right)$ for column oven was found to be the best for analysis. \% RSD was less than 2 in intraday, interday precision and all parameters of robustness are in the limit. So the proposed method is more precise, accurate and robust Table 6.

Table 6 Summary of validation parameters.

\begin{tabular}{|c|c|}
\hline Parameters & TRI \\
\hline Linear range $\left(\mu \mathrm{g} \mathrm{mL}^{-1}\right)[\mathrm{n}=6]$ & $2-12$ \\
\hline Correlation coefficient $\left(\mathrm{r}^{2}\right)$ & 0.999 \\
\hline Limit of detection $\left(\mu \mathrm{g} \mathrm{mL}^{-1}\right)$ & 0.18 \\
\hline Limit of quantification $\left(\mu \mathrm{g} \mathrm{mL}^{-1}\right)$ & 0.56 \\
\hline \% Recovery $[\mathrm{n}=3]$ & $98.52-100.24$ \\
\hline Precision $[\% \mathrm{RSD}]$ & \\
\hline Intra-day $[\mathrm{n}=3]$ & 1.43 \\
\hline Inter-day $[\mathrm{n}=3]$ & 1.29 \\
\hline Repeatability $[\mathrm{n}=6]$ & 0.73 \\
\hline Robustness & Robust \\
\hline
\end{tabular}

System suitability parameters were studied by injecting the working standard solution $(10 \mu \mathrm{g} / \mathrm{mL})$

Table 7 System suitability parameters.

\begin{tabular}{|c|c|c|}
\hline Parameters & Results & Acceptance criteria \\
\hline Theoretical plate & 7426 & More than 2000 \\
\hline USP Tailing factor & 1.38 & Less than 2 \\
\hline Capacity factor & 44.33 & Should be non zero \\
\hline USP Resolution & 11.7 & More than 2 \\
\hline
\end{tabular}

\section{CONCLUSION}

The RP-HPLC method developed and validated allows a simple and fast quantitative determination of Triflusal from bulk and formulation. A mobile phase composed of acetonitrile: $1 \mathrm{mM}$ potassium dihydrogen phosphate buffer with a short run time $(10 \mathrm{~min})$ and isocratic elution used are advantageous and made the routine analysis easy. Among the significant advantages of this method are simplicity, selectivity, accuracy and precision ensuring that it is suitable for determining the content of triflusal in capsule dosage form. Thus, the proposed method can be used for routine analysis of triflusal alone and also in combination; likewise the same can be applied to other formulations. Future plan includes further evaluation of degradants \& stability indicating method.

\section{ACKNOWLEDGEMENT}

Authors are thankful to Gleenmark Pharmaceuticals Ltd., Nasik (India), for providing gift sample of Triflusal.

\section{REFERENCES}

1. European Pharmacopoeia, 2622-23 (2005)
2. W. McNeely, K. L. Goa, Drugs, 55 (6), 823-33 (1998)

3. J. J. Ramis, R. Torrent, L. Mis, M. J. Conte, J. Barbanoj, J. Jane, Forn Int. J Clin Pharmacol Ther Toxico, 28 (8), 344-9 (1990)

4. H. Y. Cho, T. J. Jeong, Y. B. Lee, J Chromatogr B, 798 257-264 (2003)

5. J. S. Park, C. K. Park, J Liq Chromatogr R T, 23(16), 2513-2524 (2000)

6. A. Argemi, A. Lopez-Periago, C. Doming and J. Saurina. Pharm. Biomed. Anal., 46 (3), 456-462. (2008)

7. J. M. Andanson, A. Lopez-Periago, C. Garcia-Gonzalez, S. C. Domingo and J. Kazarian, Vibrational Spectroscopy, 49 (2) 183-189 (2009)

8. H. Anninos, G. Andrikopoulos, S. Pastromas, D. Sakellariou, G. Theodorakis, P. Vardas, Hellenic J Cardiol, 50 199-207 (2009)

9. V. K. Redasani, A. R. Kothavade, B. J. Mali, S. J. Surana. Der chemical sinica, 2(4) 298-302 (2011)

10. ICH (1996) Harmonized tripartite guideline: validation of analytical procedures.Q2A. 